\title{
Allelopathy in Aqueous Extract of Bixa Orellana on Euphorbia heterophylla, Raphanus sativus and Bidens pilosa
}

\author{
${ }^{1}$ Maira Cristina Schuster Russiano, ${ }^{2}$ Pedro Valério Dutra de Moraes, ${ }^{3}$ Thiago Cacção Villa, ${ }^{4}$ Carlos Guilherme \\ dos Santos Russiano ${ }^{5}$ Alberto Ricardo Stefeni, ${ }^{6}$ Rayanah Stival Svidzinski, ${ }^{7}$ Darlin Ramos
}

${ }^{1}$ Department of Agronomy, Federal Technological University of Paraná (UTFPR), Pato Branco, PR, 85503-390, Brazil

${ }^{2}$ Agronomist engineer, Teaching Agronomist engineer, Teaching Federal Technological University of Paraná (UTFPR), Dois Vizinhos, PR, 85660-000, Brazi.

${ }^{3}$ Department of Agroecosystem, Federal Technological University of Paraná (UTFPR), Dois Vizinhos, PR, 85660-000, Brazil

${ }^{4}$ Department of Agroecosystem, Federal Technological University of Paraná (UTFPR), Dois Vizinhos, PR, 85660-000, Brazil

${ }^{5}$ Department of Agronomy, Federal Technological University of Paraná (UTFPR), Pato Branco, PR, 85503-390, Brazil

${ }^{6}$ Department of Agroecosystem, Federal Technological University of Paraná (UTFPR), Dois Vizinhos, PR, 85660-000, Brazil

${ }^{7}$ Department of Agroecosystem, Federal Technological University of Paraná (UTFPR), Dois Vizinhos, PR, 85660-000, Brazil

Correspondence Author: Maira Cristina Schuster Russiano, Department of Agronomy, Federal Technological University of Paraná (UTFPR), Pato Branco, PR, 85503-390, Brazil.

E-mail: maira.schuster@homail.com

Received date: 17 September 2019, Accepted date: 18 December 2019, Online date: 31 December 2019

Copyright: () 2019 Maira Cristina Schuster Russiano et al, This is an open-access article distributed under the terms of the Creative Commons Attribution License, which permits unrestricted use, distribution, and reproduction in any medium, provided the original author and source are credited.

\begin{abstract}
Bixa orellana commonly known as urucum or colorau is very much utilized in culinary, since it is a species endowed with several chemical compounds, it becomes a good candidate to allelopathy. Given the crescent use of alternative agricultural inputs, less aggressive to the human and environmental health, the present work set as its goal to verify the allelopathy activity in the aqueous extract of Bixa Orellana on Euphorbia heterophylla, Raphanus sativus and Bidens pilosa. The adopted experimental outline has been entirely randomized, with four repetitions. The treatments were: concentrations of $1.25,2.5,5$ and $10 \%$ of aqueous extract, and witness with distilled water, conducted in germitest paper rolls with 50 seeds of wheat per soil, under temperature of $25 \% \mathrm{C}$. The length of the aerial part, root length, percentage of germination, germination speed index, vigor and average speed of germination. After the data has been tabulated, they were submitted to the Tukey test under $5 \%$ of error probability in the $\mathbf{R}$ bio software. The aqueous extract of Bixa Orellana did not present allelopathy activity on the evaluated parameters in germination of Euphorbia heterophylla and Raphanus sativus, however there has been a reduction in the average speed of germination and germination speed index of Bidens pilosa.
\end{abstract}

Keywords: Urucum, picão preto, leiteiro, nabo forrageiro

\section{INTRODUCTION}

Besides compromising the yield of a culture, weeds also reduce the quality of the final product, being it because of competition over water, light, nutrients, and space the biggest interference of weeds in cultures, besides being great hosts of plagues in cultures of interest (VARGAS e ROMAN, 2008). The study of alternative forms of chemical control of weeds is majorly necessary in consequence of the many cases of resistance show and /or tolerance to one or various chemical groups of commercial herbicides.

The usage of alternative control methods such as the use of plants extract is justified by its ecologic appeal, being used in alternative agricultural practices, due to the diversity of compounds found in the plants that are not easily spread out in a liquid environment (GUIMARÃES et al., 2014).

Bixa Orellana L. (Angiospermae: Bixaceae), commonly known in Brazil as urucum or colorau, is a perennial plant, heliophyte, pioneer and ordinary of amazon floodplain forests. Appears preferably in fertile and humid soils. It produces many seeds that are disseminated by men and animals (LORENZI, 1949).

Due to its various chemical compounds, the B. Orellana is a plant with possibilities of developing an inhibitory effect over species of weeds. There is a lack of bibliographical references in literature on this line of research. However, there are studies of other species (ZOHAIB et al. 2017). In this context, the usage of B. Orellana extract to the observation of potential effects over 
different species of weeds is necessary for detection, or not, of any mechanism of suppression of weeds that have not yet been observed. The aims of this study were to evaluate the allelopathy effect of the aqueous extract of Bixa Orellana L. on Bidens pilosa, Euphoria heterophylla and Raphanus sativus L in laboratory conditions.

\section{MATERIAL AND METHODS}

The experiment has been conducted in the Laboratório de Sementes da Universidade Technological Federal do Paraná, Campus Dois Vizinhos (UTFPR-DV), in Dois Vizinhos, PR in the month of November 2017.

The seeds of Bixa Orellana L. obtained commercially, were triturated in distilled water with the auxiliary of a domestic blender and posteriorly the gross solution was strained with commercial filter paper. In the concentrations formulation of the extract, $10 \%$ of the weight/volume has been used, that is, $100 \mathrm{gL}^{-1}$ of urucum seeds in distilled water. Based on the standard solution, distilled water dilutions were made, obtaining the remaining concentrations. The treatments were made up by the concentrations $1,25 \%, 2.5 \%, 5 \%$ and $10 \%$, besides the witness $(0 \%)$.

The weed seeds selected to the conduction of the experiment were, Euphorbia heterophylla (leiteiro), Raphanus sativus (nabo forrageiro) and Bidens pilosa (picão preto), collected a year before the experiment performance. To each species, the experimental unit has based on gerbox boxes containing 36 seeds laid over damp germiest paper with 2,5 times the weight of the paper according to RAS (BRASIL, 2009). The damping has been made with aqueous extract in accordance with the selected treatments or distilled water (witness).

Following this step, the seeds were stowed in the germination chamber, with a photoperiod of 12/12 hours light/darkness and constant temperature of $25^{\circ} \pm 1^{\circ} \mathrm{C}$. The adopted experimental outline was entirely randomized one with four repetitions.

A daily account of germinated seeds has been carried out, for a period of seven days. The following variables have been evaluated, once the number of daily germinated seeds had been obtained:

The average speed of germination (VMG/days), calculated by the equation $V M G=1 / t$ where: $t=$ average time of germination. Germination speed index (IVG): calculated by the equation $\mathrm{IVG}=\sum$ (ni /ti), where: $\mathrm{ni}=$ number of in time germinated seeds 'I'; ti $=$ time after the test installation; $\mathrm{I}=1 \rightarrow 7$ days (MAGUIRE, 1962).

The data were submitted to the Lilliefors normality test, existing no need of transformation the averages were compared by the Tukey test $(\mathrm{P} \leq 0,05)$, through the computerized application $\mathrm{R}$ (R CORE TEAM, 2015).

\section{RESULTS AND DISCUSSION}

There has been germination of the seeds of the tested species in all the treatments. As for the seeds of Euphorbia heterophylla and for the standards analyzed in this work, allelopathy interactions with the Bixa oreallana have not been observed (table 1).

Table 1: Percentage of germination (G\%), Average time of germination (TMG), Average speed of germination (VMG) and germination speed index (IVG) of Euphorbia heterophylla (leiteiro) under the effect of aqueous extract of Bixa Orellana (urucum). Dois Vizinhos - PR, UTFPR, 2019.

\begin{tabular}{|c|c|c|c|c|}
\hline Concentrations (\%) & $\mathbf{G \%}$ & TMG & VMG & IVG \\
\hline 0 & $80 \mathrm{a}^{{ }^{*}}$ & $2.42 \mathrm{a}^{{ }^{*}}$ & $0.42 \mathrm{a}^{*}$ & $45.17 \mathrm{a}^{*}$ \\
\hline 1,25 & $80 \mathrm{a}$ & $2.41 \mathrm{a}$ & $0.42 \mathrm{a}$ & $46.66 \mathrm{a}$ \\
\hline 2,5 & $80 \mathrm{a}$ & $2.67 \mathrm{a}$ & $0.38 \mathrm{a}$ & $37.50 \mathrm{a}$ \\
\hline 5,0 & $80 \mathrm{a}$ & $2.66 \mathrm{a}$ & $0.38 \mathrm{a}$ & $41.32 \mathrm{a}$ \\
\hline 10 & $80 \mathrm{a}$ & $2.14 \mathrm{a}$ & $0.48 \mathrm{a}$ & $47.33 \mathrm{a}$ \\
\hline
\end{tabular}

* The averages followed by the same letter do not statistically differ among themselves. The Tukey test has been applied to the level of $5 \%$ of probability.

In the seeds of Raphanus sativus, an effect of growing caused by the extract of Bixa Orellana to the standards of germination $(\mathrm{G} \%)$ and germination speed index (IVG) (table 2).

Table 2: Percentage of germination (G\%), Average time of germination (TMG), Average speed of germination (VMG) and germination speed index (IVG) of Raphanus sativus (nabo forrageiro) under the effect of aqueous extracts of Bixa Orellana (urucum). Dois Vizinhos - PR, UTFPR, 2019.

\begin{tabular}{|c|c|c|c|c|}
\hline Concentrations (\%) & G\% & TMG & VMG & IVG \\
\hline 0 & $80 \mathrm{~b}^{*}$ & $2.64 \mathrm{a}^{{ }^{*}}$ & $0.38 \mathrm{a}^{{ }^{*}}$ & $36.56 \mathrm{~b}^{*}$ \\
\hline 1,25 & $90 \mathrm{a}$ & $2.89 \mathrm{a}$ & $0.35 \mathrm{a}$ & $52.28 \mathrm{a}$ \\
\hline 2,5 & $90 \mathrm{a}$ & $2.55 \mathrm{a}$ & $0.39 \mathrm{a}$ & $48.24 \mathrm{ab}$ \\
\hline 5,0 & $90 \mathrm{a}$ & $2.85 \mathrm{a}$ & $0.37 \mathrm{a}$ & $44.39 \mathrm{ab}$ \\
\hline 10 & $90 \mathrm{a}$ & $2.94 \mathrm{a}$ & $0.34 \mathrm{a}$ & $45.17 \mathrm{ab}$ \\
\hline
\end{tabular}

* The averages followed by the same letter do not statistically differ among themselves. The Tukey test has been applied to a level of $5 \%$ of probability. 
In both standards $(\mathrm{G} \%$ and $\mathrm{IVG})$ it is possible to verity and increasing in the values in comparison to the witness $(0 \%)$, being bigger to the lowest concentration of the Bixa Orellana extract. For the laboratory test, this acceleration in the process of germination would not be interesting in comparison to culture, because the weed plant would have a more significant growth in the initial phase.

The compounds with allelopathy activity act as a growth inhibitor, although, in the presented case in this experiment to Raphanus sativus, it is not advised to use this extract as a phyto herbicide in the evaluated plant.

In the seeds of Bidens pilosa, the obtained results presented the interactions in the standards of the average time of germination (TMG), an average speed of germination (VMG) and in the germination speed index (IVG) (table 3).

Table 3: Percentage of germination (G\%), Average time of germination (TMG), Average speed of germination (VMG) and germination speed index (IVG) of Bidens pilosa (picão preto) under the effect of aqueous extracts of Bixa Orellana (urucum). Dois Vizinhos - PR, UTFPR, 2019.

\begin{tabular}{|c|c|c|c|c|}
\hline Concentrações (\%) & G\% & TMG & VMG & IVG \\
\hline $0 \%$ & $80 \mathrm{a}^{*}$ & $2.91 \mathrm{~b}^{*}$ & $0.35 \mathrm{a}^{*}$ & $29.50 \mathrm{a}^{*}$ \\
\hline 1,25 & $80 \mathrm{a}$ & $3.43 \mathrm{ab}$ & $0.29 \mathrm{ab}$ & $26.64 \mathrm{a}$ \\
\hline 2,5 & $80 \mathrm{a}$ & $3.52 \mathrm{ab}$ & $0.29 \mathrm{ab}$ & $26.47 \mathrm{ab}$ \\
\hline 5,0 & $80 \mathrm{a}$ & $4.02 \mathrm{a}$ & $0.25 \mathrm{~b}$ & $19.36 \mathrm{bc}$ \\
\hline 10 & $80 \mathrm{a}$ & $4.09 \mathrm{a}$ & $0.24 \mathrm{~b}$ & $17.67 \mathrm{c}$ \\
\hline
\end{tabular}

* The averages followed by the same letter do not statistically differ among themselves. The Tukey test has been applied to level of $5 \%$ of probability.

The average time of germination (TMG) of Bidens pilosa to the extract concentrations of 5,0\% and $10 \%$ presented an increase in comparison to the witness, that is, there has been a delay in the germination of the weed plant in comparison to the concentration of $0 \%$. The standard average germination speed (VMG), depicts that for the concentrations of $5,0 \%$ and $10 \%$ the initial process of development of the Bidens pilosa seedling would be affected, because a reduction in the speed of germination has been observed, even though not occurring the allelopathy effect in the germination of the seedling.

\section{CONCLUSIONS}

The aqueous extract of Bixa orellana did not present allelopathy effect under the evaluated standards in the germination of Euphorbia heterophylla and Raphanus sativus, already for the weed plant Bidens pilosa, there has been a delay in the average speed of germination, as wells as in the germination speed index, reduction the time of establishment of the weed plant.

\section{FUTURE WORKS}

Conducting different forms of extraction to the elaboration of extracts of Bixa orellana, in order to verify whether there are any effect over these and other weed plants.

\section{REFERENCES}

Brasil. Ministério da Agricultura, Pecuária e Abastecimento. Secretaria de Defesa Agropecuária. Regras para análise de sementes. Brasília: p. 399, 2009.

Guimarães, S. S.; Potrich, M.; Silva, E. R. L.; Wolf, J.; Pegorini, C. S.; Oliveira, T. M.: Ação repelente, inseticida e fagoinibidora de extratos de pimenta dedo-de-moça sobre o gorgulho do milho. Arquivo Instituto Biológico, São Paulo, v.81, n.4, p. 322$328,2014$.

Lin, D.Z.; Dong, Y.J.; Tsuzuki, E.; Sugimoto, Y.; Dong, Y.J.; Matsuo, T.H. Allelopathic effects of aqueous Aloe vera leaf extracts on selected crops. Allelopathy Journal, v. 13, p. 67-74, 2004.

LORENZI, H, 1949: Árvores brasileiras: manual de identificação e cultivo de plantas arbóreas do Brasil. Instituto Plantarum, Nova Odessa, SP, $5^{\mathrm{a}}$ ed. p.384, 2008.

Machado, A.; Conceição, A.R. Programa estatístico WinStat sistema de análise estatístico para Windows. Versão 2.0. Pelotas: UFPel, 2002.

Maguire, J.D.1962. Speeds of germination-aid selection and evaluation for seedling emergence and vigor. Crop Science, 2:176177.

Rice, E.L. 1984. Allelopathy. 2. ed. New York, Academic Press. 422 p.

R Core Team. R. A language and environment for statistical computing. R Foundation for Statistical. Computing, Vienna, Austria, 2015.

Silva, J.B.C. \& J. Nakagawa. Estudo de fórmulas para o cálculo da velocidade de germinação. Informativo ABRATES, 5(1):6273,1995

Vargas, L.; Roman, E. S.: Manual de manejo e controle de plantas daninhas. Embrapa Trigo. Passo Fundo, p. $780,2008$.

Zohaib, A.; Anjums, A.; Jabbar, A.; Tabassum, T.; Abbas, T.; Nazir, U.: Allelopathic effect of leguminous weeds on rate, synchronization and time of germination, and biomass partitioning in rice. Planta daninha, vol.35, Viçosa, p. 1-10, 2017. 